\title{
Reform in Saudi Arabia: The Case of Municipal Elections
}

\author{
Mishal Fahm Al-Sulami \\ Associate Professor of Comparative Thought \\ Islamic Studies Department, Faculty of Arts and Humanities \\ King Abdulaziz University, Jeddah, Saudi Arabia
}

\begin{abstract}
This article discusses the major positive aspects of the municipal elections of 2005, from the enlargement of freedom of expression; forging a new relationship between the public and government; involving the citizens in public responsibilities; reinforcing public collective participation; creating a new political culture; enhancing the relationship between government and society; creating a new dynamics in society; building and organizing the elections on proper bases; and to the government's neutral position towards the elections. The first election in Saudi Arabia is itself a major positive achievement heralding the dawn of a new dynamics for Saudi society.
\end{abstract}

\section{Introduction}

In the last decade, the Saudi government has undertaken some vital steps towards reforming its domestic political scene. As follows, seven main initiatives were undertaken:

1) The inauguration of a new System of Succession in the Kingdom in October $2006^{(1)}$.

2) The establishment of the King Abdulaziz Center for National Dialogue in July $2003^{(2)}$.

3) Authorization of the creation of The National Human Rights Society in March 2004.

4) Enlargement of citizens' rights to participate in domestic affairs, i.e., municipal elections.

5) Amendment of Articles 23 and 3 of the Shura Council's Statutes in November 2003 and April 2005, respectively ${ }^{(3)}$. 
6) Restructuring of some governmental institutions to enhance their efficiency and performance ${ }^{(4)}$.

7) Widening women's scope for work and giving them more freedom in economic activities ${ }^{(5)}$.

Given its unique importance, and the limitations of time and space, this article evaluates the Saudi electoral experience only. The evaluation process should cover both the positive and the negative aspects of the electoral experience. Because of space considerations, this article focuses only on the positive aspects of the elections. It assesses the governmental aspects in two parts: the legislative - "laws and bylaws"; and the organizational part - "running the electoral process". It also probes society's point of view and public response to the elections with regard to participation and compliance with the related regulations. The evaluation criteria used in this research are based on international standards in order to determine whether elections are democratic or not ${ }^{(6)}$. However, as a caution, the Saudi electoral experience is not expected to meet, at least in its initial stages, all international criteria. Moreover, these elections are not to be compared with those held in advanced countries with many years of experience in universal suffrage and in organizing democratic elections.

There are nine fundamental positive aspects, which came out of the first Saudi electoral experience: Enlargement of freedom of expression; forging a new relationship between the public and government; involving the citizens in public responsibilities; reinforcing public collective participation; creating a new political culture; enhancing the relationship between government and society; creating a new dynamics in society; building and organizing the elections on proper bases; and the government's neutral position towards the elections. Each of these aspects is discussed in details.

\section{First: Enlargement of Freedom of Expression}

The major and the most prominent positive outcome of the first electoral experience in Saudi Arabia is the contribution the elections brought to the enlargement of freedom of expression. Citizens now talk openly to some extent, about Saudi society's problems and other issues of interest, be it in public places, in electronic forums or to a lesser degree 
through the press and public opinion polls. The elections were an appropriate occasion to highlight the problems of Saudi society, to bring them to greater public awareness, to discuss them in the open with transparency and clarity, to give them greater scrutiny, and as well as to put forward solutions and suggestions to these problems.

Thus, some candidates for the municipal elections included in their electoral programs and agendas issues that were not within the municipal board's competence. These issues pertain to general social problems such as unemployment, poverty, anti-corruption, women's rights to drive, creation of cinemas, increasing civil service salaries, and fighting obesity $^{(7)}$. However, it is not correct to say that candidates talked about matters that were beyond the municipal board's competence simply because, as had been suggested by certain political analysts, they were ignorant of the prerogatives and competences of the municipal board. One of the main reasons why they raised these matters in their electoral programs was that they were given forum of freedom and took the opportunity to talk about matters they thought were the main concerns of the citizens, as these matters were directly related to their daily life. In addition, candidates talked about these matters to let the voters know their electoral programs and to allow them the opportunity to make the best choice. Open democratic election campaigns were like marketing in which candidates were essentially vote maximizers who needed to put forward their programs in order to attract the widest spectrum of the electorate.

Moreover, a fundamental relationship exists between elections and freedom. This requires that the elections reflect the real will and ambitions of the people in a free atmosphere in which the candidate is given the chance to present his electoral programs to the voters without any direct or indirect obstacles, and in which the voter can vote for his/her favorite candidate without any form of coercion, threat or fear of reprisal $^{(8)}$. In their famous book Comparative Government and Politics, Rode Hague, Martin Harrop and Shaun Breslin (1998) set seven criteria for free elections:

1) Freedom of speech.

2) Freedom of association.

3) Freedom to register as a voter or a candidate.

4) Freedom from coercion and intimidation. 
5) Freedom of access to the polling stations.

6) Freedom to vote in secret.

7) Freedom for the candidate or the voter to complain about the election's outcome ${ }^{(9)}$.

Further more, the relationship between elections and freedom is directly proportional: The more freedom given to voters, candidates and the media, the more credible are the elections in reflecting the voters' choice; and vice versa.

As a major breakthrough, the Saudi municipal elections have achieved six of the above-mentioned criteria. Freedom of association (authorizing the existence of both political parties and pressure groups) was the only criterion believed not to have been fulfilled. This limitation resulted because of the system of candidature for the elections according to which candidates should be independent individuals, not nominees of political parties $^{(10)}$. The fact that the first Saudi electoral experience met six out of the seven criteria of free and fair elections is a positive achievement which we should talk about in glowing terms.

However, more initiatives should be taken to implant the elections' positive principles and values such as freedom of speech, principle of free choice, taking laws and legislation as norms, pluralism, respecting contradictory opinions, and accepting defeat in society, by inserting them into public education curricula. The seventh criterion, freedom of association, could not be fulfilled because it was prohibited by law. The case can be understood and analyzed on the basis of the kind of political and social culture prevalent, not only of the Kingdom, but in all GCC countries as well. In these countries, political partisanship is regarded as dangerous to national unity as well as social cohesion.

\section{Second: Forging a New Relationship between the Public and Government}

For the first time, the elections contributed to reshaping the relationship between the citizens and government officials on new bases involving accountability, transparency and criticism. While the elected official is held accountable by the voters, however, the appointed official, is questioned or called to account directly by the one who appointed him. 
Whoever has the authority to appoint someone has also the authority of holding him responsible.

However, although elections have now entered the political and social life in the Kingdom, this is not the case. Officials in both the Legislature and Executive are all appointed by the King, except 50\% of the members of the Municipal Councils who are now elected by the citizens.

In its first electoral experience, however, we noticed that the degree to which both citizens and the media criticize appointed officials is not less than the degree to which they criticize elected officials. The reason is that the elections have introduced new concepts of freedom, transparency and accountability of public authorities into Saudi society. As a result of these new concepts, the relationship between citizens and officials has been reshaped regardless of whether those officials are elected or appointed. Citizens have now become empowered: Public officials are subject to criticism and questioning by citizens and the media alike. For instance, we noticed that former expressions like "Everything is OK", "Thanks to Allah, there is no problem" and other similar expressions which denote satisfaction and acceptance and which used to be repeated by appointed officials of the government, are no longer acceptable in the new Saudi social and political context. Such expressions are replaced by others describing the true status and reality of society. Examples of these new expressions are: "the existence of chronic problems", "incomplete services", "we are sorry for the inadequacy, and we shall make our utmost efforts to resolve problems and mistakes". As a result of the elections, the degree of responsiveness of governmental officials to citizens has increased markedly.

\section{Third: Involving the Citizens in Public Responsibilities}

It should be noted that the Saudi citizen was for a long time not only barred from running public affairs, but deprived of the right to question those in charge of running society's business and public life as well. As a result, a culture of lethargy, unwillingness and lack of interest developed among Saudi citizens. Because of citizens' traditional non-involvement in public life, we now notice in our society certain negative attitudes that are incompatible with religious values, moral criteria, and social customs. These include for example, striking aggression against public utilities, 
corruption, undisciplined behavior of those employed by the government, as well as non-observance of good conduct in driving.

The elections therefore contributed positively in addressing inappropriate attitudes by shifting the citizens from a state of simple observers, negative criticism, non-participation and incapacity to action, to a state of being an active and resourceful participant with public responsibility. Indeed, the elections gave citizens - voters and candidates alike - a share in running the country. Hence, the citizen is now empowered and feels a part of society, as he contributes together with his fellow citizens in assuming public responsibilities.

It should be emphasized that the recent Saudi municipal elections were partial only. They were not general parliamentary elections for the Shura Council where elected officials would legislate on all aspects of public and national life, such as political, economic, cultural, social, educational and utility affairs. Nonetheless, the elections, for the first time, empowered citizens to elect half of the Council's members. The other half is appointed by the government.

It is worth noting that the Municipal elections constituted just a first necessary step in the right direction. At this initial stage, they serve to train citizens in sharing responsibility for governing and running society's local and public affairs. It is therefore vital that this first stage should be followed progressively by other successive stages with the aim of enlarging citizens' participation in all aspects of government and at all levels - local (Municipal Councils) as well as national (Shura Council). This could be achieved incrementally: As the next progressive step, elect $2 / 3$ of the members of the Municipal Councils in forthcoming elections; then in future elections, elect the whole Council, as well as strengthening the Councils' powers.

Once this enlargement is achieved at the local level, the next logical step is naturally to expand elections to the Shura Council. As a start, elect $1 / 3$ of its members, then progressing later to $2 / 3$, and finally the whole in the eventual future. At this stage, the Shura Council may be gradually transformed from a Consultative Council into a full-fledge Legislative Parliament with all its attendant rights, responsibilities and privileges.

It should be pointed out that the culture of elections in Saudi Arabia which started with local elections has extended well beyond the 
municipality to include almost all non-governmental organizations set up after the first 2005 elections. It now includes the various professional societies, such as journalists, engineers, lawyers, and economists. Both members and heads of these societies are elected. Elections also are taking place in the Chambers of Trade and Commerce. Half of the members of these Chambers including their Presidents are as well elected. Indeed, in some professional societies, such as the Jeddah Chamber, all members of the committees are now chosen by elections.

\section{Fourth: Reinforcing of Public Collective Participation}

The 2005 municipal elections served to reinforce the spirit of public collective participation. The Saudi citizen is neither trained nor used to participating in public life, especially in the field of politics. This is why we noticed certain poor attitudes related to the exercise of public collective action in this first experience, three of which are worth noting: overly-aggressive or excessive actions, boycotting, and violation and trickery of the elections' organizing bodies. Some candidates even engaged in excessive measures in order to win the elections. They made use of all their material instruments, social relations, as well as posted their photos and displayed their electoral programs everywhere in the streets and on the front pages of daily newspapers. In addition, some candidates organized electoral camps with various cultural programs (religious lectures, social and economic forums) as well as a variety of sumptuous and delicious meals and drinks. These were like feasts, not simply attracting the attention of voters, but marking the prelude of their victory.

However, certain citizens publicly boycotted the elections. They did not make the least effort to learn about the elections, or to take part in them, either as voters or as candidates. They opposed the elections for seven major reasons: Novelty of the electoral experience; society's apathy towards public affairs; appointing half of the Municipal Councils' members; the limited nature of the Municipal Council's scope of action; ambiguity of the municipal council's function; lack of satisfaction with the project of municipal elections; and strong conviction in the Municipal Council's inefficiency ${ }^{(11)}$.

Others took part in the elections without complying with the rules by using deception and trickery. As a result of this situation, we noticed the 
absence of two key factors capable of deciding the elections' results positively or negatively: Competition and fairness. The 'Recommended Lists $^{{ }^{(12)}}$, for instance, are regarded as an act that violated these two factors. The 'Recommended Lists' were chosen by certain local clerical religious and prominent preachers who worked hard distributing the lists in a well-organized manner through electronic forums and mobile phones, in order to back up certain candidates. It should be pointed out that the candidates on 'The Recommended Lists' won the elections in most major Saudi cities, such as Makkah, Madina, Riyadh, Jeddah and Taif.

It should be emphasized that collective act or participation is a fundamental Islamic principle. Most Islamic rites (e.g., the five daily prayers, fasting in the Holy month of Ramadan, Hajj or Pilgrimage) are all to be done collectively. Therefore, Saudi society needs to take the following steps in adhering strictly to this cardinal principle:

1) Make theoretical arguments for the principle of the collective act in the field of public political life, by highlighting religious and rational justifications, as well as the historical Islamic examples. This is to emphasize that collective action is legitimate in Islam and constitutes an integral part of Muslim life in which all citizens are consequently obligated to take part. It is also fundamental to clarify that elections are not a Western instrument only applicable in such societies; Muslims must make use of elections to choose their leaders and govern their affairs as legislated by Islam.

It should be stated that the Shura, which is one of the basic principles of government in Islam, cannot work except through elections and mutual participation of the members of society ${ }^{(13)}$. Allah the Almighty ordered Muslims to run their public affairs through Shura ${ }^{(14)}$. The ideal form of Shura is general elections in which all members of society take part ${ }^{(15)}$. As a frank admission, most Muslims are sensitive and critical about taking anything from Western civilization into their societies. But we must distinguish between two aspects: the positive aspects of modern Western civilization from which other societies might benefit, and those aspects that are only compatible with the particular cultural and religious background of Western societies only. Democracy principles, their associated institutions and values are classified in the first aspect. 
2) Benefiting from the experiences of other countries and societies in organizing the instruments, mechanisms and institutions needed for collective action in the field of public political life, especially from those countries which have had long experiences in organizing, developing and modernizing institutions, mechanisms and instruments related to public political life. As a caution, benefiting from the experience of the others does not mean copying or blindly imitating wholesale their experiences or systems. We should take only the positive aspects based on the requirements of our own society.

Nevertheless, we have to emphasize that the principles and basic institutions needed for public political collective acts (e.g., the rule of law, general elections, guaranteeing for all citizens the right of political participation, political pluralism, peaceful transfer of power, separation of powers, guaranteeing the independence of the judiciary, safeguarding human rights and liberties, majority rule, and political representation) are something which most, if not all, modern societies have unanimously agreed upon. Still, it is worth indicating that there is room for differences between countries concerning the institutions, laws and legislations through which the collective public political act is organized, as these parameters originate from the cultural and political heritage of every society. For instance, countries like the UK, France and Germany have adopted general elections as an instrument of choosing their public officials for both Legislative and Executive powers. However, the electoral systems being used are different from one country to another. The UK has adopted the system of Relative Majority (RM), while in France a system of a Simple Majority (SM) is being used. As for Germany, it has adopted a system of Proportional Representation $(\mathrm{PR})^{(16)}$.

3) Developing mechanisms and instruments as well as setting up norms and laws for the public political collective act that are compatible with the nature and composition of Saudi society. In this context, two points should be clarified:

a) Developing does not mean inventing new principles and institutions for the public political collective act, but rather developing instruments and mechanisms out of the indigenous pre-existing basic principles and institutions which are applied in every society. This means adopting the basic principles and institutions for the public political 
collective act, while also developing instruments, mechanisms, and laws that would be compatible with the religious and cultural heritage of Saudi Arabia.

b) The Saudi society is conservative, but at the same time modernistic. This does not imply a contradiction between the two elements. The Saudi society is conservative with regard to ancestral values, Islamic teachings and social traditions and customs. The tribe and the family are still the cornerstone of Saudi social structure. The individual's degree of compliance with Islamic social values, customs and good manners is a good indication of the judgment to be delivered about him: Either to accept or to reject him, to consider him either a righteous person or a bad one, and either to deal or not to deal with him. This has become a social law everybody has to comply with.

As for modernism, the Saudi society is modernistic as far as modern technology is concerned. It is perhaps the only Arab state, by virtue of its oil wealth, that has more widely and rapidly embraced new technology. Saudi universities, for example, have not only adopted the most sophisticated and modern teaching methods, e.g., Distance Learning and Closed Circuit TVs., but make use of the most modern techniques for information conveyance (e.g., PowerPoint and Overhead Projectors) and communication with students as well (through Electronic Home Pages). Thus, both conservatism and modernism are positive elements that should be harmonized and employed in a positive manner to back up the public political collective act. This can be done through inserting Islamic values and good manners into the laws and norms governing elections, and using new technology in the organization of such elections.

Indeed, as far as the first element, conservatism, is concerned, some of its meanings have already been enshrined in Article 29 of The Regulations of Electing the Municipal Councils' Members, which stipulates the obligatory compliance with good Islamic manners (i.e., not to disturb law and order, not to provoke dissention or any factional, tribal or regional conflict, not to offend either the voters or the other candidates, whether directly or indirectly, and prohibiting the use of both mosques and public utilities for electoral campaigns). The article also confirms that society's traditions and customs must be respected ${ }^{(17)}$. 
As for the second element - modernization - its techniques were not adopted in the elections' governing mechanisms and instruments. The elections' three main phases (registering both the voters and the candidates, voting process, and accounting and sorting out of the voices) were all carried out by traditional methods, i.e., by hand, not by technology. The government should - in addition to using traditional methods - incorporate modern methods in conducting elections. The internet may be a prominent tool for organizing the electoral process (including both registering voters, and the voting process), so citizens could register and vote electronically without the need to go to the polling station.

\section{Fifth: Creating a New Political Culture}

Indeed the 2005 elections' contributed to the creation of a new culture that would reorder the priorities of Saudi society. As a result of the elections, the National and Internal Agenda have been pushed forward, and have become the center of interest for society, the government and the media alike. In the past, the Foreign Affairs have dominated a great deal of interest and have resulted in a considerable extent to sidelining the National and Domestic Agenda. The Saudi society has embraced nearly all the Muslim world's problems (e.g., the Palestinian problem; the situation in Afghanistan; Serb and Croatian attack against Bosnian Muslims; the Russian intervention in Chechnya; the US invasion and occupation of Iraq; in addition to the problems of Muslim minorities around the world) to which it gives its utmost moral and financial support. It must be emphasized that the Saudi society's concern about the problems of the Arab and Muslim world as well as its support for their legitimate causes, is not only positive in its own right, but highlights the unique status and pivotal importance of Saudi Arabia in the Arab and Muslim Worlds. Indeed, the rest of the world could hardly ignore this reality.

As a result of Saudi Arabia's unique place in the Arab and Islamic Worlds and its attendant obligations therein, this has tended to work to the disadvantage of domestic problems and the issues that concern the life and well-being of every Saudi. For instance, it was common to face great delays in addressing and finding prompt solutions for local issues. The result was that many issues accumulated and emerged as serious 
problems at the same time, and it was difficult for the government and society to deal simultaneously with so many problems, both chronic and new.

It should be noted that the elections played a pivotal role in pushing society to reorder its priorities and focus first on the National Agenda as something natural. Thus, priority was given to domestic and national affairs, while regional or international issues became secondary. The elections have given society a great deal of freedom and citizens started to publicly express their real concerns and problems as well as their future ambitions, most, if not all of, which concern domestic affairs. The clearest manifestation that the municipal elections were to instigate Saudi society to reorder its priorities by putting the domestic and national agenda before other concerns is the candidates' electoral programs, even though they discussed matters that do not fall within the prerogatives of the Municipal Councils. It is noteworthy that they did not mention any subject relating to regional or international affairs. Instead, they concentrated only on issues related to domestic and national affairs, such as poverty, unemployment, reform of the school curricula, helping young people to get married, increasing the salaries of civil servants, authorizing women to drive cars, and the creation of movie theatres.

\section{Sixth: Enhancing the Relationship between Government and Society}

The Saudi government took a strategic decision to enlarge the circle of popular participation and to implement certain reforming initiatives namely, municipal elections. Two main objectives stand behind this decision: enhancing the relationship between government and society, and strengthening the government's position at the international stage.

Internally, the elections contributed to establishing closer working relations between citizens and government. Although it is alleged that the government faced a ferocious campaign from Al Qaeda and the militant cells inside the Kingdom which aim to harm it, implementing the municipal elections was not only a courageous stand or simply a reaction; it was indeed a prudent political step.

Moreover, the Saudi government experiences pressures from the outside as well, namely from the US, its historical ally, asking it to reform its educational, economic and political systems (e.g., Greater 
Middle East Initiative in 2004). Thus, Municipal elections for local consumption also simultaneously responded to demands form the international arena. There are also Islamist, liberalist and independent voices from within Saudi society echoing calls for reforms (e.g., "Letter of Demands" in 1991, "Advice Memorandum" in 1993, "Petition of the Vision of the Present and the Future of Saudi Arabia" in 2002, and "Petition of the Message to the Saudi Leadership and People: Constitutional Reform First" in 2003).

An important fact that is often neglected is that the Saudi government itself believes in reform. King Abdullah is widely regarded as a "Reformer Leader". He launched many such reformative projects in the two years of his reign, whether in the form of systems, legislations or executive laws. On the top of these reformative projects were two very important systems: The System of Succession in 2006, and the New Judicial System in $2007^{(18)}$.

The willingness of the government and its response to those voices calling for reforms are manifested by its commitment to hold the first municipal elections. This proves its seriousness and further assures citizens that practical steps are taken and reform is not a mere theory. Thus, the elections resulted in reinforcing the relationship between society and government. Moreover, the government's domestic political initiatives also resulted in praises from the international front. The elections usually work as an exchange of influence between the society and the government ${ }^{(19)}$. They place on society the duty of taking up its responsibilities as well as sharing with the government the task of running public affairs. As a benefit to both society and government, the latter gains from the elections as they reinforce the citizens' loyalty to it, strengthen the cohesion between the leaders and the people, organize the relationship between the government and society, as well as increasing the government's legitimacy.

In the same way, the citizen benefits from the elections as he enters into a mutual partnership with the government in taking up responsibility for public affairs. Although the first Saudi elections were limited to municipal and not general sphere, it however should be noted that the municipal services constitute one of the most important aspects of the citizen's daily life. For instance, safe and sanitary sewage disposal, garbage disposal, cleanliness of the city or town, paving and lighting of 
roads, developing and maintaining public parks, connecting households to potable water sources, are all key services that the citizen is primarily concerned about.

\section{Seventh: Creating New Dynamics in Society}

The elections contributed to the creation of new dynamics in society with regard to politics and information. Although the Saudi elections were partial in which half of the members of the Municipal Council were elected, while the other half are appointed, and approximately half of society was entitled to take part in the elections (males aged 21 years and over), they broke new grounds and set in motion internal trends that called for reforms. The atmosphere that accompanied the elections was even more impressive and had more impact than the elections themselves. The elections opened the door for claims to greater involvement of citizens in running not only political affairs, but other affairs of society as well. In the same way, the elections contributed to some extent to granting the media, especially the press, more freedom to discuss and analyze important issues, including domestic (e.g., the collapse of the Saudi Stock Market and its negative impact on ordinary citizens, rising up the price of basic goods, poverty, and unemployment) and international matters (e.g., questing the historical relationship between the Kingdom and the US, and the link between the American dollar and the Saudi Riyal).

As far as politics is concerned, the question of enlarging the circle of participation in decision-making was raised. This should be done through the election of the Shura Council's members and transforming it from a Consultative Council into a Parliament with both legislation and scrutinizing powers. In the same way, all members of the Municipal Council should be elected, with the enlargement of its jurisdiction. Another topic discussed was the need to increase the role of women in society by giving them the right to take part in public life, such as the right to vote and being allowed to become an electoral candidate, enlarge the kinds of jobs available to her, and discuss her social demands and problems openly. Indeed, participatory rights of being involved in the decision-making process should not be limited just to politics; it should also extend to cover educational affairs, like the demand for electing the heads of departments and deans of university and colleges, granting 
universities more administrative and financial independence, as well as creating elected councils for students.

As for the media, the elections contributed clearly in granting the public media more freedom in discussing the issues and problems of society. The press raised questions that are related to Saudi internal affairs which were considered taboo in the past, such as reforming the school curricula particularly with regard to religious subjects, the role of the Commission of Commanding Good and Prohibiting Evil, public debt, women's right to drive cars, poverty and unemployment.

It should be pointed out that the press should play a meaningful and constructive role in order for the elections to succeed. In the modern world, electoral success or failure depends on the degree to which the media responds to the elections positively or negatively. Thanks to the media's modern technology, it is now a key point of contact between the citizen and the elected official. Thus, the media should do the following to increase and strengthen support for the success of municipal elections:

1) To highlight society's demands and problems related to municipal affairs, through reporting of opinions, ideas and analyses that discuss those demands and problems.

2) To keep its eye on the Municipal Councils' degree of response to the said demands and problems, as well as on its capacity to bring about satisfactory solutions.

3) To evaluate the projects and laws passed by the Municipal Council, point out both the positive and the negative aspects of such laws and projects, as well as to introduce suggestions in overcoming the negative aspects.

4) To measure public opinion with regard to the performance of the elected Municipal Councils and their members, as there is no specialized center to carry out this job.

\section{Eighth: Building and Organizing the Elections on Proper Bases}

The first Saudi electoral experience was distinguished for being well-organized, transparent, as well as for the easiness of the procedures used for registration, applying as a candidate for the elections and for keeping to its timetable. This contributed not only to encouraging the citizens to respond positively to the elections, but to a positive image of the whole process, from the international community's point of view as 
well. The fact that the Saudi government managed the elections professionally and complied with internationally-agreed standards was something quite positive, as it proved the government's determination to faithfully implement the reform projects that it announced. These projects were related not only to politics, but to education, economic, social and women's affairs as well. With the implementation of the said projects, the government enhanced its credibility in the opinion of both Saudi citizens and the world community. The Saudi government's success in organizing the first electoral experience was due to its sincere political willingness and commitment towards vital reforms in Saudi society. Indeed, in order to assure the success of the elections, it moved to:

1) Pass legislation (laws, regulations and instructions) and issue the decisions covering the whole electoral process, from the administrative, organizational or legal point of view.

2) Respect strictly the previously-fixed dates for the elections' different phases (voters' registration, issue lists of the voters, candidates' registration, publish the primary list of candidates, make sure of the candidates' eligibility to stand, publish the final list of candidates, and keep the voting day).

3) Study the various experiences of countries known to have proven expertise and long traditions of organizing public elections. In the same way, benefiting from the world specialized bodies known to have long expertise in providing consultations in matters of organizing public elections, such as the United Nations Development Program (UNDP).

Good organization, transparency and facilitating the registration procedures for voters and candidates, and compliance with the declared schedules for the different phases of the elections, are all key elements not only for the elections' success, but truly for the elections themselves as well. Conversely, setting difficult and complicated electoral procedures to register either the voters or the candidates, postponing the voting date without any valid reason, or not publishing the voters' lists, are aspects that can lead people to doubt the sincerity, credibility, and neutrality of the government with regard to elections. Such a practice would also call the elections' fairness or impartiality into question and further discourage public participation. It is remarkable that this did not happen in the municipal elections in Saudi Arabia. 
Indeed, the more the government complies with the declared schedules for the phases of the elections, or acts with transparency with regard to the elections, or simplifies the procedures for registering both the voters and the candidates (by using IT), the more the elections are successful, either with regard to their political outcomes as the expression of the citizens' real choice, or with regard to the level of public participation.

\section{Ninth: The Government's Neutral Position towards the Elections}

Neutral state, as P. Jones has pointed out, is the "one that deals impartially with its citizen and which remains neutral on the issue of what sort of life they should lead"(20). In order to make the elections free, fair and impartial, the Saudi government has laid down laws and instructions organizing the elections, and in the same way, the competent ministry (Ministry of Municipal Affairs and Villages) has issued the regulations organizing the elections and supervising all its phases. However, this was all done according to international procedures and customs, and in a very professional and neutral manner, extricating the government of any charge of vested interest or ulterior motives.

The government's neutrality with regard to the elections can be verified through the follow up and the evaluation of three aspects: political, legislative and organizational. These not only determine the development of the elections, but affect the elections' outcomes as well:

1) Politically, the Saudi government neither backed nor opposed, directly or indirectly, any candidate. In the same way, there were no candidates running on its behalf or candidates promoting its policies. Instead, the government dealt with all candidates equally, with impartiality and with reference to the laws and regulations in case of any infringement of electoral procedures. The government also prohibited certain governmental officials, such as chiefs of districts, and chiefs of Interior Ministry centers from running in the elections, so that they would not take advantage of their official influence on voters or hinder other candidates.

2) Legislatively, the electoral regulations (laws and instructions issued by the Council of Ministers, and the regulations issued by the Ministry of Municipal Affairs and Villages) were enacted on objective grounds ${ }^{(21)}$. The regulations did not bias the chances of particular 
candidates to win, to the disadvantage of others. Instead, they aimed to implant fairness and impartiality among all contenders, without any differentiation or preferential treatment. However, this does not mean that the electoral regulations issued by the government were ideal or perfect, but they contained a lot of positive aspects that have to be reinforced in future elections. In the same way, they have some shortcomings that need to be addressed. Nevertheless, it should be confirmed that the existence of any perceived negative aspect in the said regulations neither cancels nor affects the principle of neutrality which is the basis of legislating regulations governing the elections.

3) Organizationally, the government has managed the elections on the principles of transparency, no segregation between the candidates, compliance with the elections' previously declared timetable, selection of qualified people to conduct the elections, and the distribution of constituencies within cities and villages in accordance with the number of voters. These positive organizational parameters prove once again not only the government's neutral position towards the elections, but its sincerity and commitment to organize credible elections as well.

The Saudi government's neutral position and its non-intervention in the elections' outcomes, as well as its keenness that the elections represent a true expression of the people's will, are all positive elements that contributed greatly to the success of the first Saudi electoral experience. These elements are to be reinforced and maintained in future elections.

\section{Conclusion}

The municipal elections that were organized in 2005, distinguished by the eligibility of all citizens, who met the basic legal conditions, to participate in all cities and villages of the Kingdom are considered a major turning point in Saudi society at the beginning of the third millennium.

The elections' importance lies in its influence on society, which was not just limited to politics, but goes well beyond other aspects of public, social, economic and private life. With the first Saudi elections, the relationship between the government and society has been reshaped and strengthened. New concepts have entered into Saudi society, such as freedom, transparency, criticism and accountability of public authorities. 
Moreover, the elections have created a barrier-free atmosphere that allows citizens to criticize the government and talk publicly about their problems. The media and in particular the press also have benefited from this opportunity by discussing and highlighting issues that were considered taboo in the past, i.e., reforming the religious school curricula, corruption, and the public debt.

The first Saudi municipal elections of 2005 are a laudable departure from the widespread practices of corruption, manipulation and interference in elections prevalent in other Arab and Third World countries. The Kingdom has shown good face and demonstrated its sincerity, willingness and commitment to hold Municipal elections all across the nation. However, it now needs to expand the scope of the electoral process in Saudi Arabia and strengthen its instruments in order to encourage the widest possible public participation of all Saudi citizens to the exclusion of none and enlarge the scope of elections to the highest pinnacle of government institutions at the Executive and Legislative levels. This move will strengthen the bond between citizens and rulers, increase patriotism, loyalty and work to the mutual benefit and interests of all. There should be no turning back here on.

\section{Endnote}

(1) See "The System of Succession", issued by virtue of the Royal Decree No. A/135, 20 October 2006.

(2) So far, the Centre has met five times to discuss five "hot" topics. These topics have been, and are still being debated in Saudi public places The first meeting discussed "National Unity and Pluralism"; the second meeting concentrated on "Exaggeration and Moderation"; the third meeting looked at "Women's Issues"; the fourth meeting focused on "Youth's Issues"; and the fifth meeting dealt with "Dialoguing with the Other".

(3) The Article 3 increases the number of Council Members from 120 to 150, thereby broadening the range of citizens' representation in the Council. While the Article 23 states that the Council should be given the right to take initiatives toward suggesting, amending and updating draft regulations. In addition, it creates the post of Shura Affairs State Minister, in order to foster coordination between Council of Ministers and the Shura Council.

(4) For example, cutting off "Labor" from the Ministry of Social Affairs and creating a separate Labor Ministry; cutting off "water" from Agriculture Ministry and creating a new Ministry called "Water and Electricity"; incorporating "General Presidency for Girls' Education" with "The Ministry of Education"; and shifting "Cultural Affairs" from "Youth Care General Presidency" to "Information Ministry" and renaming the latter as "Culture and Information Ministry".

(5) Moreover, the government also set up a women's section in those governmental bodies that provide women with related services. It is as well considering the possibility of setting up a National Higher Standing Committee for Women's Affairs. 
(6) The most distinguished international norms judging the democratization of any elections are four: 1) the elections should be a competitive run, free, periodical, and open to the participation of all citizens; 2) the state institutions and bodies' commitment to remain neutral vis-à-vis the candidates; 3) setting up an electoral supervising, independent and neutral committee; and 4) enabling the candidates to reach the voters.

(7) See the following Newspapers: Sharq Al Awsat, Wednesday 2 February 2005, Issue No. 9563; Thursday 3 February 2005, Issue No. 9564; and Tuesday 8 February 2005, Issue No. 9569; Al Madina, Wednesday 23 February 2005, Issue No. 15281; Al Watan, Wednesday 20 April 2005, Issue No. 1664; and Okaz, Thursday 21 April 2005, Issue No. 14117.

(8) See R. Dahl, On Democracy, (New Haven and London: Yale University Press, 1998), pp. 85, 95-96; and J, Elklit and P. Sevensson, What Makes Elections Free and Fair, 1997, Journal of Democracy, Vol. 8, No. 3, pp: 34-35.

(9) See R. Hague, M. Harrop and S. Breslin, Comparative Government and Politics: An Introduction, Fourth Edition, (Malaysia: MACMILLAN Press LTD, 1998), p. 99.

(10) See Article 12, The Regulations of Electing the Municipal Councils' Members, issued by virtue of the Ministerial Resolution No. 38396, 1 August 2004.

(11) For more details about these seven major causes, See Mishal Al-Sulami, The Negative Aspects of the First Saudi Electoral Experience: A Critical Study, Under Publication.

(12) The 'Recommended Lists' comprised names of candidates approved by some revered religious scholars and prominent preachers for their uprightness and fair conduct.

(13) For more details about the System of Shura, and how it works, and the points of agreements and differences between Shura and Democracy, See Mishal. Al-Sulami, The West and Islam: Western Liberal Democracy versus the System of Shura, (London and New York: Routledge Curzon, 2003), pp: 37-60, 198-203; and J. Esposito and J. Voll, Islam and Democracy, (New York and Oxford: Oxford University Press, 1996), pp: 11-32.

(14) The word of Shura is mentioned twice in the Holy Qu'ran: a) in Chapter of Al-Shura, Verse No. 38: "And those who answer the call of Allah, and perform regular prayer, and who [conduct] their affairs by mutual consultation, and spend out of what we have given them." b) Also in Chapter Al-Imran, Verse No. 159: "Thus it is a mercy of Allah that thou art lenient unto them; had you been cruel and hard-hearted, they would have surely dissipated around you; therefore, ask forgiveness for them, pardon them, and consult them on the conduct of [their] affairs, and when you are resolved, put your trust in Allah, Allah loves those who trust [in Him]."

(15) There are ample evidences that support the notion that Shura cannot work except through elections and mutual participation of the members of the society. Ahmed Al-Razi (one of the prominent interpreters of the Holy Quran) comments on Verse No. 38 in Chapter Shura: "And those who answer the call of Allah, and perform regular prayer, and who [conduct] their affairs by mutual consultation..." saying that the Ansar community did not take any decision in their affairs unless all of them consented to do so (See Ahmed Al-Razi, Kitab Ahkam AL-Quran, Mutbi'at Al-Wqaf Al-Islamiyah, 1915, vol. 27, p. 177). The second Rightly Guided Caliph, Umar Ibn Al-Khatab said clearly: "Whoever swears allegiance to anyone without consultation with the Muslims, will be invalid and both of them will be subject to being killed" (See Shihab Al-Din Ahmed Al-Qastalani, Irshad al-Sari Sharih Sahih Al-Bukhari, Vol. 10, Beirut: Dar al-Kitab Al-Arabi, 1903, p. 19). He also said to Ibn Abbas: "Take from me three things: ...the Caliphate is based on consultation..." (See Abdalrazzaq Al-Sana'ani, Al-Musanaf, Vol. 5, Beirut: Al-Maktab Al-Islami, 1983, p. 446). Additionally, the fourth Rightly Guided Caliph, Ali bin Abi Talib, emphasized this point very clearly: "Oh people...it is your right to choose your leader. No one has to claim this right except the one whom you chose" (See Ali Ibn Al-'Athir, Al-Kamil Fi Al-Tarikh, Vol. 3, Beirut: Dar Sadir, 1979, p. 99). In modern times, one can find many Muslim scholars and thinkers who argued for elections as a means of implementing Shura. Among them are Abu Al-'Ala Al-Mawdudi, Muhammad A'sd, and Muhammad Al-'Arabi (See Abu 'Ala Al- 
Mawdudi, Naziriyat Al-Islam Wa Hadyah fi Al-Siyasah wa Al-Qanun wa Al-Distur, Beirut: Dar Al-Fikr, 1967, p. 290; Muhammad A'sd, Manhaj Al-Islam fi Al-Hukm, Translated into Arabic by Mansur Madi, Beirut: Dar Al-Ilm Lilmallyyn, 1964, p. 91; and Muhammad Al'Arabi, Nizam Al-Hakm fi Al-Islam, Beirut: Dar Al-Fikr, 1968, p. 84).

(16) For more details about different types of electoral systems, See R. Dahl, On Democracy, (New Haven and London: Yale University Press, 1998), pp: 130-141; V. Bogdanor, 'Introduction', in V. Bogdanor and D. Butler (eds.), Democracy and Elections: Electoral Systems and Their Political Consequences, (Cambridge: Cambridge University Press, 1983), pp. 1-16; and R. Rose, 'Elections and Electoral Systems: Choices and Alternatives', in V. Bogdanor and D. Butler (eds.), Democracy and Elections: Electoral Systems and Their Political Consequences, (Cambridge: Cambridge University Press, 1983), pp: 30-37.

(17) See Article 12, The Regulations of Electing the Municipal Councils' Members, op. cit.

(18) See "The System of Judiciary and the System of the Board of Grievances", issued by virtue of the Royal Decree No. M/78, 1 October 2007.

(19) See M. Harrop and W. Miller, Elections and Voters: A Comparative Introduction, (London: Macmillan, 1987), pp: 253-54.

(20) See P. Jones, 'The Ideal of the Neutral State', in R. Goodin and A. Reeve (eds.), Liberal Neutrality, (London: Routledge, 1989), p. 9.

(21) The Council of Ministers issued "The System of Municipalities and Villages", 10 February 1977; while the Ministry of Municipal Affairs and Villages issued three regulations: The Regulations of Electing the Municipal Councils' Members, 1 August 2004, Instructions Governing the Electoral Campaigns, 20 October 2004; and The Municipal Councils' Codes of Practice of 1426 H, 14 December 2005.

\section{References}

Al-'Arabi, M. (1968) Nizam Al-Hukm fi Al-Islam (in Arabic), Beirut, Dar Al-Fikr.

Al Madina, Wednesday 23 February 2005, Issue No. 15281.

Al-Mawdudi, Abu 'Ala (1967) Naziriyat Al-Islam Wa Hadyah fi Al-Siyasah wa Al-Qanun wa AlDistur, Beirut, Dar Al-Fikr.

Al-Qastalani, Shihab Al-Din Ahmed (1903) Irshad al-Sari Sharih Sahih Al-Bukhari, Vol. 10, (in Arabic), Beirut, Dar al-Kitab Al-Arabi.

Al-Razi, A. (1915) Kitab Ahkam Al-Quran, Vol. 27, (in Arabic), Mutbi'at Al-Wqaf Al-Islamiyah.

A'sd, M. (1964) Manhaj Al-Islam fi Al-Hukm, Translated into Arabic by Mansur Madi, Beirut, Dar Al-Ilm Lilmallyyn.

Al-Sana'ani, A. (1983) Al-Musanaf, Vol. 5, (in Arabic), Beirut: al-Maktab Al-Islami.

Al-Sulami, M., The Negative Aspects of the First Saudi Electoral Experience: A Critical Study, Under Publication.

Al-Sulami, M. (2003) The West and Islam: Western Liberal Democracy Versus the System of Shura, London and New York, Routledge Curzon.

Al Watan, Wednesday 20 April 2005, Issue No. 1664.

Bogdanor, V. (1983) 'Introduction', in Bogdanor, V. and Butler, D. (eds.), Democracy and Elections: Electoral Systems and Their Political Consequences, Cambridge, Cambridge University Press.

Dahl, R. (1998) On Democracy, New Haven and London, Yale University Press.

Elklit, J. and Sevensson, P. (1997) What Makes Elections Free and Fair, 1997, Journal of Democracy, 8(3) (1997).

Esposito, J. and Voll, J. (1996) Islam and Democracy, New York and Oxford, Oxford University Press.

Hague, R., Harrop, M. and Breslin, S, (1998) Comparative Government and Politics: An Introduction, Fourth Edition, Malaysia, Macmillan Press Ltd. 
Harrop, M. and Miller, W. (1987) Elections and Voters: A Comparative Introduction, (London: Macmillan, 1987).

Ibn Al-'Athir, A. (1997) Al-Kamil Fi Al-Tarikh, Vol. 3, in Arabic, Beirut, Dar Sadir.

Jones, P. (1989) 'The Ideal of the Neutral State', in Goodin, R. and Reeve, A. (eds.), Liberal Neutrality, London: Routledge.

Ministerial Resolution No. 38396, 1 August 2004, The Regulations of Electing the Municipal Councils' Members.

Ministerial Resolution No. 66866, 14 December 2005, The Municipal Councils' Codes of Practice of $1426 \mathrm{H}$.

Okaz, Thursday 21 April 2005, Issue No. 14117.

Rose, R. (1983) 'Elections and Electoral Systems: Choices and Alternatives', in Bogdanor, V. and Butler, D. (eds.), Democracy and Elections: Electoral Systems and Their Political Consequences, Cambridge, Cambridge University Press.

Royal Decree No. M/5, 10 February 1977, The System of Municipalities and Villages.

Royal Decree No. M/78, 1 October 2007, The System of Judiciary and the System of the Board of Grievances.

Royal Decree No. A/135, 20 October 2006, The System of Succession.

Sharq Al Awsat, 2005:

- Wednesday 2 February, Issue No. 9563.

- Thursday 3 February, Issue No. 9564.

- Tuesday 8 February, Issue No. 9569. 


\title{
الإصلاح في المملكة العربية السعودية: نموذج الانتخابات البلدية
}

\author{
مشعل فهم محمد السئمي \\ أستاذ الفقه الدقارن المشارلك بقسم الدراسات الإسلادية \\ كلبة الآداب و العلوم الإنسانية - جامعة الملك عبدالعزبز \\ جلة - المدلكة العربية السعودية
}

المستخلص. البحث يحاول در اسة التجربــة الانتخابيــة الـسعودية

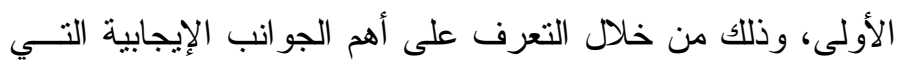

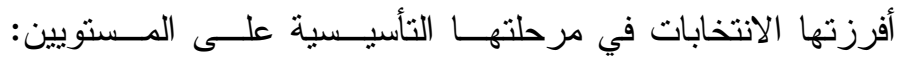

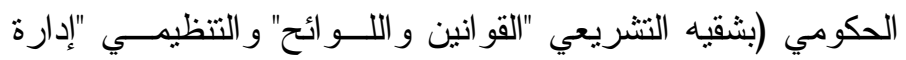

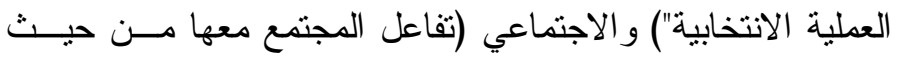

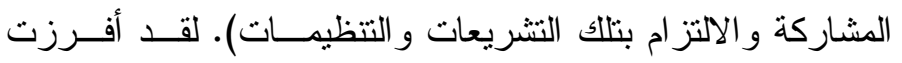

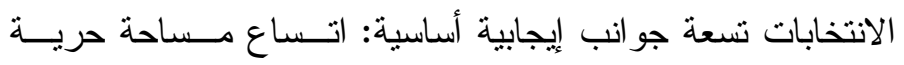

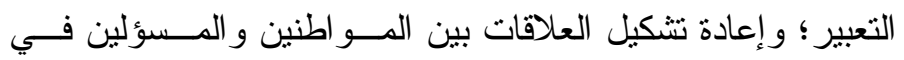
الحكومة على أسس جديدة؛ ومشاركة المو اطنين الحكومة في تحمل المسؤولية العامة؛ وتعزيز روح المشاركة في العمل الجماعي العام؛

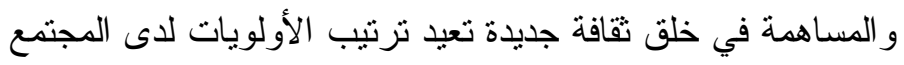

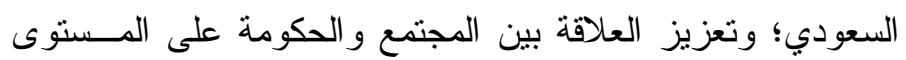
الداخلي، وتقوية موقف الحكومة على المستوى الدولي؛ و المساهمة

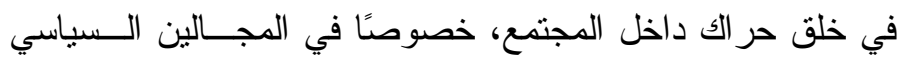

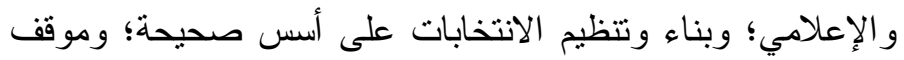
الحكومة الحيادي من العملية الانتخابية. 